\title{
OVERWEIGHT AND OBESITY PREVALENCE OF LATVIAN PRE-SCHOOL CHILDREN
}

\author{
Liene Martinsone-Bērzkalne, \\ Silvija UmbrašKo, Ilva Duţevska \\ Department of Anatomy and Anthropology, Riga Stradiňš University, Latvia
}

\begin{abstract}
This data is a part from the study ordered by the Ministry of Education to assess physical development of pre-school children in Latvia. Various somatometric measurements were determined - height $(\mathrm{cm})$, the body mass $(\mathrm{kg})$, the circumference of the head, chest, waist, hips $(\mathrm{cm})$, vital lung capacity $(\mathrm{ml})$, blood pressure $(\mathrm{mm} / \mathrm{Hg})$ and other parameters. This study evaluates the body mass index (BMI), overweight and obesity prevalence of pre-school children. Comparing the data with the data of other European countries, we can conclude how high the prevalence of overweight and obesity in our country is and what are potential activities to reduce the prevalence.
\end{abstract}

Keywords: prevalence; overweight; obesity

\section{INTRODUCTION}

Overweight and obesity is a worldwide problem. The World Health Organization maintains that in 2014 more than 1.9 billion adults, 18 years and older, were overweight. Of these 600 million were obese [4]. In 2014, an estimated 41 million children under the age of 5 were overweight or obese [4]. Obesity is a chronic disease that is complex and multifactorial in nature [6]. The main causes of obesity are genetic factors and environmental factors. Obesity is a significant cause in cardiovascular diseases, diabetes, musculoskeletal disorders and some types of cancers. Childhood obesity is associated with a higher chance of obesity, premature death and disability in adulthood [4]. 


\section{THE AIM}

To assess and analyze the body mass index (BMI), overweight and obesity of pre-school children (age 4-7).

\section{MATERIAL AND METHODS}

In the study there were 995 children - 527 girls and 468 boys involved from 22 different Riga pre-school educational institutions. Children were 4 to 7 years old. Anthropometric measurements were done by R. Martin's and K. Saller's methods (1957-1966). All the instruments in measurements were certified. Weight $(\mathrm{kg})$ and height $(\mathrm{cm})$ were detected. The Formula BMI = weight $(\mathrm{kg}) /$ height ${ }^{2}(\mathrm{~m})\left(\mathrm{kg} / \mathrm{m}^{2}\right)$ was used for the body mass index. For obtained results SPSS and MS Excel programs were used.

\section{RESULTS AND DISCUSSION}

The average height of four-year-old girls is $103.2 \pm 5.7 \mathrm{~cm}(\min .85 .9 \mathrm{~cm}$; max. $128.2 \mathrm{~cm}$ ). In the group of five-year-old girls the average height is $110.7 \mathrm{~cm}$ $\pm 4.9 \mathrm{~cm}$ (min. $96.6 \mathrm{~cm}$; max. $124.2 \mathrm{~cm}$ ). In the group of six-year-old girls the average height is $117.7 \pm 5.7 \mathrm{~cm}(\min .104 .0 \mathrm{~cm}$; $\max .131 .7 \mathrm{~cm})$ but in the group of seven -year-old girls it is $122.5 \pm 5.4 \mathrm{~cm}(\min .104 .4 \mathrm{~cm}$; $\max$. $139.2 \mathrm{~cm}$ ).

In the group of four-year-old boys the average height is $105.1 \pm 4.7 \mathrm{~cm}$ (min. $90.0 \mathrm{~cm}$; max. $120.4 \mathrm{~cm}$ ). The average height of five-year-old boys is $111.8 \pm$ $5.4 \mathrm{~cm}(\min .99 .6 \mathrm{~cm}$; max. $131.0 \mathrm{~cm})$. The average height of six-year-old boys is $118.7 \pm 4.9 \mathrm{~cm}(\min .103 .4 \mathrm{~cm}$; $\max .131 .3 \mathrm{~cm})$. In the group of seven-yearold - boys it is $124.4 \pm 4.7 \mathrm{~cm}$ (min. $113.6 \mathrm{~cm}$; max. $135.8 \mathrm{~cm}$ ). In Table 1 the difference of height results between age groups of both genders is shown.

We compared our data with the data of other European countries. Thus, in Larsen et al. study the data of children in Denmark are similar to ours. The height of four-year-old girls was $1.05 \pm 0.05(\mathrm{~m})$ and in the group of five-yearold girls it was $1.12 \pm 0.05(\mathrm{~m})$ [3]. The height of four-year-old boys was $1.04 \pm$ 0.05 , in the group of five-year-old boys it was $1.13 \pm 0.05$ [3].

In our study the body mass of four-year-old girls is $16.8 \pm 2.4$ ( $\mathrm{min} .10 .0$, max. 22.7). In the group of five-year-old girls body mass is $19.2 \pm 2.9$ (min. 12.5, max. 28.0), in the group of six-year-old girls it is $22.1 \pm 3.9$ (min. 15.5; max. 36.0). Finally the body mass in the group of seven-year-old girls is $23.7 \pm$ 3.5 (min. 14.5; max. 34.1). Looking at the male gender the data of the study are 
similar to the female gender. The body mass of four-year-old boys is $17.7 \pm 2.3$ ( $\min .12 .6$; max. 25.1), of five-year-old boys it is $19.6 \pm 2.8$ ( $\min .14 .0$; max. 36.5). In the group of six-year-old boys the body mass is $21.9 \pm 3.5$ ( $\mathrm{min} .16 .7$; max. 36.0) and in the group of seven-year-old boys it is $24.9 \pm 3.7$ ( $\mathrm{min}$. 19.6; max. 40.0). The data about the body mass in pre-school children are shown in Table 2.

We compared our data with the situation in Denmark. In Larsen et al. study the weight of four-year-old girls was $17.59 \pm 2.54$ and in the group of five-yearold girls it was $19.06 \pm 2.97$ [3]. The weight of four-year-old boys was $17.27 \pm$ 2.18 , in the group of five-year-old boys it was $20.11 \pm 2.76$ [3].

Table 1. Children's body length.

\begin{tabular}{lccccc}
\hline Gender & Age & $\mathbf{N}$ & $\begin{array}{c}\text { Average height } \\
(\mathbf{c m})\end{array}$ & $\begin{array}{c}\text { Minimum height } \\
(\mathbf{c m})\end{array}$ & $\begin{array}{c}\text { Maximum height } \\
(\mathbf{c m})\end{array}$ \\
\hline \multirow{3}{*}{ Girls } & 4 & 116 & $103.2 \pm 5.7$ & 85.9 & 128.2 \\
\cline { 2 - 6 } & 5 & 154 & $110.7 \pm 4.9$ & 96.6 & 124.2 \\
\hline & 6 & 136 & $117.7 \pm 5.7$ & 104.0 & 131.7 \\
\hline \multirow{3}{*}{ Boys } & 105 & $122.5 \pm 5.4$ & 104.4 & 139.2 \\
\hline & 5 & 95 & $105.1 \pm 4.7$ & 90.0 & 120.4 \\
\hline & 6 & 127 & $111.8 \pm 5.4$ & 99.6 & 131.0 \\
\hline & 7 & 90 & $124.4 \pm 4.7$ & 113.6 & 131.3 \\
\hline
\end{tabular}

Table 2. Children's body mass.

\begin{tabular}{lccccc}
\hline Gender & Age & $\mathbf{N}$ & $\begin{array}{c}\text { Average body } \\
\text { mass }(\mathbf{k g})\end{array}$ & $\begin{array}{c}\text { Minimum body } \\
\text { mass }(\mathbf{k g})\end{array}$ & $\begin{array}{c}\text { Maximum body } \\
\text { mass }(\mathbf{k g})\end{array}$ \\
\hline \multirow{3}{*}{ Girls } & 4 & 116 & $16.8 \pm 2.4$ & 10.0 & 22.7 \\
\cline { 2 - 6 } & 5 & 154 & $19.2 \pm 2.9$ & 12.5 & 28.0 \\
\hline & 6 & 136 & $22.1 \pm 3.9$ & 15.5 & 36.0 \\
\hline \multirow{3}{*}{ Boys } & 7 & 105 & $23.7 \pm 3.5$ & 14.5 & 34.1 \\
\hline & 4 & 95 & $17.7 \pm 2.3$ & 12.6 & 25.1 \\
\hline & 5 & 127 & $19.6 \pm 2.8$ & 14.0 & 36.5 \\
\hline & 7 & 136 & $21.9 \pm 3.5$ & 16.7 & 36.0 \\
\hline
\end{tabular}


In our study also the average value of the children's height growth rate per year $(\mathrm{cm} /$ year) in each age group and gender was calculated. The largest increase of height per year for girls in the age group 4-5 years was $7.5 \mathrm{~cm} /$ year, but for boys in the age group 5-6 years it was $6.9 \mathrm{~cm} /$ year. These data are shown in Table 3. The average value of children's weight growth rate per year $(\mathrm{kg} / \mathrm{year})$ in each age group and gender was calculated. The largest increase of weight per year for girls in the age group 5-6 years was $2.9 \mathrm{~kg} / \mathrm{year}$, for boys in age group 6-7 years it was $3.0 \mathrm{~kg} /$ year. These data are shown in Table 4.

Table 3. Average value of children's height growth rate per year.

\begin{tabular}{lcccc}
\hline \multirow{2}{*}{ Gender } & \multicolumn{5}{c}{ Age (groups) } \\
\cline { 2 - 5 } & $\mathbf{3}$ to $\mathbf{4}$ & $\mathbf{4}$ to $\mathbf{5}$ & $\mathbf{5}$ to $\mathbf{6}$ & $\mathbf{6}$ to $\mathbf{7}$ \\
\hline Girls & 3.0 & 7.5 & 7.0 & 4.8 \\
\hline Boys & 5.2 & 6.7 & 6.9 & 5.7 \\
\hline
\end{tabular}

Table 4. Average value of children's weight growth rate per year.

\begin{tabular}{lcccc}
\hline \multirow{2}{*}{ Gender } & \multicolumn{5}{c}{ Age (groups) } \\
\cline { 2 - 5 } & $\mathbf{3}$ to $\mathbf{4}$ & $\mathbf{4}$ to $\mathbf{5}$ & $\mathbf{5}$ to $\mathbf{6}$ & $\mathbf{6}$ to $\mathbf{7}$ \\
\hline Girls & 0.1 & 2.4 & 2.9 & 1.6 \\
\hline Boys & 1.4 & 1.9 & 2.3 & 3.0 \\
\hline
\end{tabular}

The body mass index was calculated next during our study. Table 5 shows the results in each age group and gender group. The data of the body mass index in other European populations are similar to ours. Thus, in Larsen et al. study of the population in Denmark the BMI of four-year-old girls is $15.90 \pm 1.68$, the BMI of five-year-old girls is $15.60 \pm 1.74$. The BMI of four-year-old boys is $15.84 \pm 1.15$, but in the group of five-year-old boys it is $15.71 \pm 1.55$ [3].

After that all the children in our study were divided into three groups according to the BMI. The first group, BMI-1, included the children whose BMI against weight and height is under $85^{\text {th }}$ percentile. The second group, BMI-2, included the children with overweight and the BMI in this group was between $85^{\text {th }}$ and $94^{\text {th }}$ percentile. The third group, BMI-3, included the children with obesity and the BMI there was more than $94^{\text {th }}$ percentile. In Table 6 there is an absolute and relative incidence of pre-school children body mass index in accordance with the BMI standards shown. Final results showed that there were 
$12.5 \%$ of girls and $11.1 \%$ of boys with overweight in pre-school educational institutions. Obesity was found in $4.2 \%$ of girls and $5.1 \%$ of boys of pre-school age.

Table 5. Children's body mass index.

\begin{tabular}{lccccc}
\hline Gender & Age & $\mathbf{N}$ & $\begin{array}{c}\text { Average body } \\
\text { mass index } \\
\left(\mathbf{k g} / \mathbf{m}^{2}\right)\end{array}$ & $\begin{array}{c}\text { Minimum body } \\
\text { mass index } \\
\left(\mathbf{k g} / \mathbf{m}^{2}\right)\end{array}$ & $\begin{array}{c}\text { Maximum body } \\
\text { mass index } \\
\left(\mathbf{k g} / \mathbf{m}^{2}\right)\end{array}$ \\
\hline \multirow{3}{*}{ Girls } & 4 & 116 & $15.8 \pm 1.2$ & 12.6 & 19.5 \\
\cline { 2 - 6 } & 5 & 154 & $15.6 \pm 1.7$ & 9.2 & 22.1 \\
\hline & 6 & 136 & $15.8 \pm 2.0$ & 10.9 & 24.0 \\
\hline \multirow{3}{*}{ Boys } & 7 & 105 & $15.7 \pm 1.6$ & 12.9 & 22.1 \\
\hline & 4 & 95 & $15.9 \pm 1.2$ & 13.0 & 19.4 \\
\hline & 5 & 127 & $15.6 \pm 1.4$ & 12.7 & 24.0 \\
\hline & 7 & 136 & $15.5 \pm 1.6$ & 12.5 & 22.0 \\
\hline
\end{tabular}

Table 6. Absolute $(\mathrm{N})$ and relative (\%) incidence of the pre-school children body mass index (in accordance with the BMI standards).

\begin{tabular}{|c|c|c|c|c|c|c|c|c|c|c|}
\hline & \multicolumn{8}{|c|}{ Age } & \multicolumn{2}{|c|}{ Total } \\
\hline & \multicolumn{2}{|c|}{4} & \multicolumn{2}{|c|}{5} & \multicolumn{2}{|c|}{6} & \multicolumn{2}{|c|}{7} & \multirow[b]{2}{*}{$\mathbf{N}$} & \multirow[b]{2}{*}{$\%$} \\
\hline & $\mathbf{N}$ & $\%$ & $\mathbf{N}$ & $\%$ & $N$ & $\%$ & $\mathbf{N}$ & $\%$ & & \\
\hline \multicolumn{11}{|c|}{ Girls } \\
\hline BMI-1 & 92 & 79.3 & 129 & 83.8 & 112 & 82.4 & 96 & 91.4 & 439 & 83.3 \\
\hline BMI-2 & 21 & 18.1 & 18 & 11.7 & 14 & 10.3 & 7 & 6.7 & 66 & 12.5 \\
\hline BMI-3 & 3 & 2.6 & 7 & 4.5 & 10 & 7.4 & 2 & 1.9 & 22 & 4.2 \\
\hline Total & 116 & 100.0 & 154 & 100.0 & 136 & 100.0 & 105 & 100.0 & 527 & 100.0 \\
\hline \multicolumn{11}{|c|}{ Boys } \\
\hline BMI-1 & 77 & 81.1 & 108 & 85.0 & 115 & 84.6 & 77 & 85.6 & 392 & 83.8 \\
\hline BMI-2 & 12 & 12.6 & 15 & 11.8 & 13 & 9.6 & 7 & 7.8 & 52 & 11.1 \\
\hline BMI-3 & 6 & 6.3 & 4 & 3.1 & 8 & 5.9 & 6 & 6.7 & 24 & 5.1 \\
\hline Total & 95 & 100.0 & 127 & 100.0 & 136 & 100.0 & 90 & 100.0 & 468 & 100.0 \\
\hline
\end{tabular}


If we look at overweight and obesity in separate groups and compare them to other data some differences arise. In Denmark the population overweight in four-year-old girls is $10.9 \%$ but obesity in the same group 2.9\%. Overweight in four-year-old boys is $7.1 \%$ but obesity $2.3 \%$ [3]. Boneberger et al. study shows the situation in Bavaria, Germany. In the group of 5-6-year-old children $16 \%$ of girls and $11.7 \%$ of boys are overweight but $3.3 \%$ of girls and $3.5 \%$ of boys have obesity [2]. W. Ahrens et al. study shows the baseline condition of overweight and obese children (age 2.0-9.9) in several European countries [1]. The study displays the problem in Italy, Estonia, Cyprus, Belgium, Sweden, Germany and Hungary. Total data of all the countries show that $11.8 \%$ of boys and $13.8 \%$ of girls have overweight but $6.8 \%$ of boys and $7.3 \%$ of girls have obesity [1]. Scandinavian countries like Estonia and Sweden have similar data to ours. Thus, Estonia has overweight of $10.2 \%$ of boys and $10.8 \%$ of girls and obesity of $3.6 \%$ of boys and $4.2 \%$ of girls [1]. But data in Sweden shows a better situation - 7.7\% of boys and $9.9 \%$ of girls have overweight and $2.4 \%$ of boys and $2.1 \%$ of girls have obesity. Data of Italy data show that overweight and obesity there is quite a serious problem. $20.8 \%$ of boys and $24.3 \%$ of girls have overweight but $19.9 \%$ of boys and $19.8 \%$ of girls are obese [1].

\section{CONCLUSIONS}

1. The average value of height for boys (age 4-7) is higher than for girls in the same age. The value of height increase on average is about $19.3 \mathrm{~cm} /$ per year for both genders.

2. The highest increase of height growth rate per year for girls in the age 4-5 on average is $7.5 \mathrm{~cm}$ per year. For boys in the age 5-6, it is on average $6.9 \mathrm{~cm}$ per year.

3. The average value of the body mass essentially does not differ for both genders in the pre-school age.

4. The average increase of the body mass per year is equal for both genders.

5. The highest increase of the body mass for girls is at age 5-6 but for boys it is in the age group 6-7.

6. In pre-school age $11.8 \%$ of children ( $12.5 \%$ of girls and $11.1 \%$ of boys) have overweight but $4.6 \%$ of children ( $4.2 \%$ of girls and $5.1 \%$ of boys) have obesity. 


\section{REFERENCES}

1. Ahrens W., Pigeot I., Pohlabeln H., Henauw S., Lissner L. Molnár D., Moreno L.A., Tornaritis M., Veidebaum T., Siani A. (2014). Prevalence of overweight and obesity in European children below the age of 10. International Journal of Obesity, 38, S99-S107.

2. Boneberger A., Kries von R., Milde-Busch A., Bolte G., Rochat M.K., Rückinger S. (2009). Association between peer relationship problems and childhood overweight/obesity. Acta Paediatrica 2009, 98, 1950-1955.

3. Larsen L.M., Hertel N.T., Mølgaard C., Christensen R.P., Husby S., Jarbøl D.E. (2012). Prevalence of overweight and obesity in Danish preschool children over a 10-year period: a study of 2 birth cohorts in general practice. Acta Paediatrica, 101, 201-207.

4. Obesity and overweight. Fact sheet (2016). http://www.who.int/mediacentre/ factsheets/fs311/en/

5. Selga G., Lāriņš V., Sauka M. (2008). Liekās ķermeṇa masas un aptaukošanās problēma Latvijas skolēniem. Doctus, 7, 20-24.

6. Serra-Majem L., Ribas-Barba L., Pérez-Rodrigo C., Ngo J., Aranceta J. (2007). Methodological limitations in measuring childhood and adolescent obesity and overweight in epidemiological studies: does overweight fare better than obesity? Public Health Nutrition, 10(10A), 1112-1120.

\section{Address for correspondence:}

Liene Martinsone-Bērzkalne

Riga Stradiņš University

Institute of Anatomy and Anthropology

Kronvalda blvd. 9, Riga, LV-1010, Latvia

E-mail: liene.martinsone@gmail.com 